\title{
HER2 Receptor Overexpression in Gastric Adenocarcinoma A Study about a Sampling of 50 Cases in Dakar
}

Gaye AM1, Niang $\mathrm{D}^{2}$, Bentefouet $\mathrm{TL}^{3 *}$, Keita $\mathrm{A}^{4}$, Thiam $\mathbf{I}^{1}$, Dieme Ahouidi MJ ${ }^{4}$ and Moustapha Dial CM${ }^{5}$

${ }^{1}$ Aristide le Dantec University Hospital, Laboratory of Pathological Anatomy and Cytology, Senegal

${ }^{2}$ Laboratory of Pathological Anatomy and Cytology, Saint Louis Regional Hospital, Senegal

${ }^{3}$ Laboratory of Pathological Anatomy and Cytology of Thiès Regional Hospital, Senegal ${ }^{4}$ Laboratory of Pathological Anatomy and Cytology, Fann University Hospital, Senegal

5Pathological Anatomy and Cytology Service, Grand Yoff General Hospital, Senegal

\section{Research Article}

Volume 4 Issue 3

Received Date: July 10, 2019

Published Date: December 10, 2019

DOI: $10.23880 /$ oajmb-16000151

*Corresponding author: Tonleu Linda Bentefouet, anatomopathologist. Thiès Regional Hospital, Pathological Anatomy and Cytology Unit, Avenue Malick Syprolongée; BP 34A Thiès RP, Senegal, Tel: (221) 775420730 ; Email: camairla@yahoo.fr

\section{Abstract}

Introduction: HER2 receptor overexpression in gastric or gastroesophageal junction (GOJ) adenocarcinoma is a factor of poor prognosis detected in 7 to $34 \%$ of gastric and GOJ adenocarcinomas. The objective of this study was to evaluate the overexpression of the HER2 receptor in gastric adenocarcinomas in Dakar, and to investigate the correlation between HER2 overexpression and clinicopathological parameters.

Patients and method: This is a retrospective, descriptive and analytical study that was conducted over a one-year period; from 1 January 2016 to 31 December 2017. It involves 50 cases of gastric or G0J adenocarcinomas histologically confirmed on biopsy samplings, collected within pathological anatomy and cytology services in Dakar (HALD and HOGGY). The study of HER2 receptor overexpression was performed on tumor samples put in buffered formalin and embedded in paraffin using the immunohistochemical method.

Results: The average age was $58.18 \pm 14.6$ years. A male predominance was observed, with a gender ratio of 1.27 . Tumors were ulcero budding in $76 \%$ of cases. They were found at the gastric level in $92 \%$ of the surveyed cases, and at the gastroesophageal junction in $8 \%$ of them. Adenocarcinomas were of tubulous type in $76 \%$ of cases, and they were markedly differentiated in $54 \%$ of cases. At immunohistochemical study, the positivity rate of the HER2 was $8 \%$ out of 
the 50 cases that were tested. There was no correlation between HER2 overexpression and those clinicopathological parameters .

Conclusion: HER2 is a factor of poor prognosis but it is also a therapeutic response factor to anti-HER2s. Assessment of the HER2 status should be systematic in all cases of gastric adenocarcinoma; and it requires a multidisciplinary approach.

Keywords: Gastric adenocarcinoma; HER2; Dakar

\section{Introduction}

Gastric cancer is a type of cancer with poor prognosis, with $65 \%$ of cases diagnosed at a locally advanced and metastatic stage [1]. An overexpression and / or amplification of HER2 was detected in 7-34\% of gastric adenocarcinomas. That overexpression is thought to represent both a factor of poor prognosis and of correct answer regarding new "targeted" therapies which are essential, with the use of an anti-HER2 antibody (trastuzumab) to obtain more chances of survival [2,3]. Today, not all gastric cancers are systematically tested for HER2 status. The objective of the study was to estimate the prevalence of HER2 receptor overexpression in gastric or gastroesophageal junction (GOJ) adenocarcinomas in Dakar; and to study the correlation between the overexpression of HER 2 and clinicopathological parameters.

\section{Patients and Methods}

The present study is a retrospective, descriptive and analytical study conducted over a 1-year period, from
January 1, 2017 to December 31, 2017. The study was initially performed in the pathological anatomy and cytology (ACP) departments of Aristide Le Dantec Hospital (HALD), and in the Grand Yoff General Hospital (HOGGY), all located in Dakar. Only adenocarcinomas from our study have been classified according to the WHO 2010 International Classification of Diseases (ICD-10) [4]. As such, fifty (50) tissue blocks of patients with a gastric or JOG adenocarcinoma condition on biopsy were included after initial formalin fixation and paraffin impregnation according to standard techniques. The other tumorous types were discarded from the study. Analysis of HER2 status by immunohistochemistry was performed in 2 private pathological anatomy and cytology laboratories in Tunis (Tunisia) and Bordeaux (France). The HercepTest ${ }^{\circledR}$ Dako Kit was used, providing A485 polyclonal antibodies and slides for quality control, containing three cell lines with coloring intensity scores of 0 to $3+$. The results were expressed in score (Table 1 ) and were based on the intensity of the membrane marking and the percentage of marked cells (at least 5 adjacent cohesive cells).

\begin{tabular}{|c|c|c|c|}
\hline $\begin{array}{c}\text { Coloring } \\
\text { intensity: } \\
\text { IHC Score }\end{array}$ & $\begin{array}{c}\text { Surgical samplings Coloring } \\
\text { model }\end{array}$ & Biopsy samplings coloring model & HER2 Status \\
\hline 0 & $\begin{array}{c}\text { Not reactivity or membrane } \\
\text { reactivity in }<10 \% \text { of tumorous } \\
\text { cells }\end{array}$ & $\begin{array}{c}\text { Not reactivity or membrane reactivity in any (or less } \\
\text { than 5) tumorous cells }\end{array}$ & Negative \\
\hline $1+$ & $\begin{array}{c}\text { Very weak membrane reactivity in } \\
310 \% \text { of tumorous cells }\end{array}$ & $\begin{array}{c}\text { Group of tumorous cells with very weak membrane } \\
\text { reactivity, regardless of the percentage of colored } \\
\text { tumorous cells (at least 5 tumorous cells) }\end{array}$ & Negative \\
\hline $2+$ & $\begin{array}{c}\text { Membrane reactivity that is total, } \\
\text { basolateral or lateral, weak to } \\
\text { moderate in at least 10\% of } \\
\text { tumorous cells }\end{array}$ & $\begin{array}{c}\text { Group of tumorous cells presenting membrane } \\
\text { reactivity that is total, basolateral or just lateral to } \\
\text { moderate to weak, regardless of the percentage of } \\
\text { colored tumorous cells (at least 5 tumorous cells) }\end{array}$ & $\begin{array}{c}\text { Ambiguous (ISH } \\
\text { evaluation } \\
\text { required) }\end{array}$ \\
\hline $3+$ & $\begin{array}{c}\text { Strong membrane reactivity that is } \\
\text { complete, basolateral or lateral in } \\
\text { only 10\% of tumorous cells }\end{array}$ & $\begin{array}{c}\text { Group of tumorous cells presenting a strong } \\
\text { membrane reactivity that is complete, basolateral or } \\
\text { lateral, regardless of the percentage of colored } \\
\text { tumorous cells (at least 5 tumorous cells) }\end{array}$ & Positive \\
\hline
\end{tabular}

Table 1: Immunohistochemical score criteria used for the evaluation of HER2 status in gastric cancers [5]. 
Data were collected from records of reports from anatomopathological examinations of patients and additional reports of immune histochemical examinations to study HER2 receptor overexpression. Then, they were transcribed again on a survey sheet which included the following elements:

- Demographic data: age, gender.

- Anatomopathological data: tumor location, macroscopic aspect (by endoscopy), histological type, and HER2 status.

Data entry was performed on an Excel spreadsheet. Statistical analysis of the data was carried out using the SPSS 20.0 software under Windows 10. For each statistical test used, the significance threshold was limited at $\mathrm{p} \leq 0.05$.

\section{Results}

Epidemiological Data: The average age of patients was $58.18 \pm 14.6$ years, with extremes of 24 and 93 years. The most represented age group was patients aged between 50 and 70 years, which represented $56 \%$ of all cases (Figure 1). A male predominance was observed with a 1.27 gender ration.

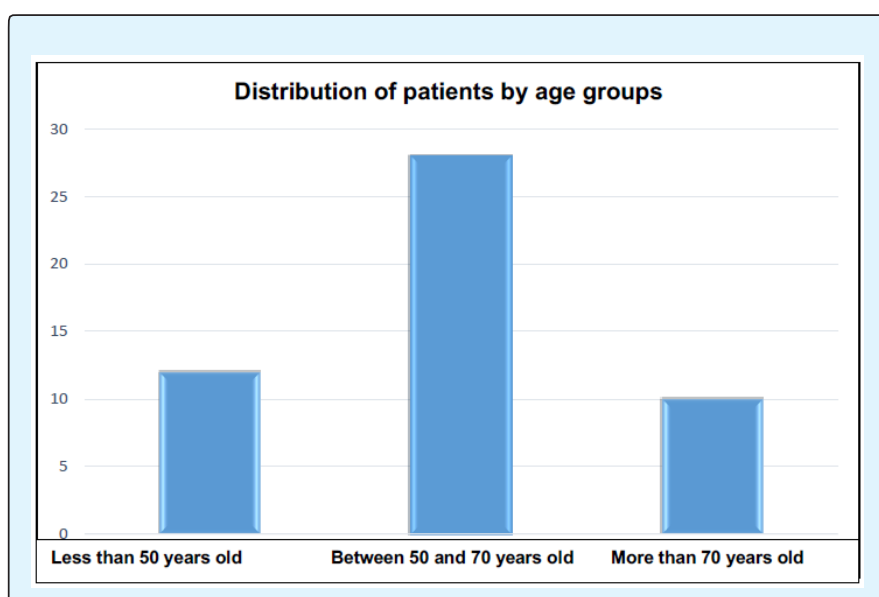

Figure 1: Distribution of patients by age groups.

\section{Anatomopathological Data}

Tumors were located at the gastric level in 46 patients (92\% of cases), and at the gastroesophageal junction in 4 patients ( $8 \%$ of cases). At the gastric level, the antro pyloric localization was the most frequent case with 31 patients; which represents $64 \%$ of cases (Figure 2). Tumors had an ulcero budding appearance in $76 \%$ of cases (38 patients), a budding appearance in $14 \%$ of cases (7 patients) and an ulcerated appearance in $10 \%$ of cases (5 patients).

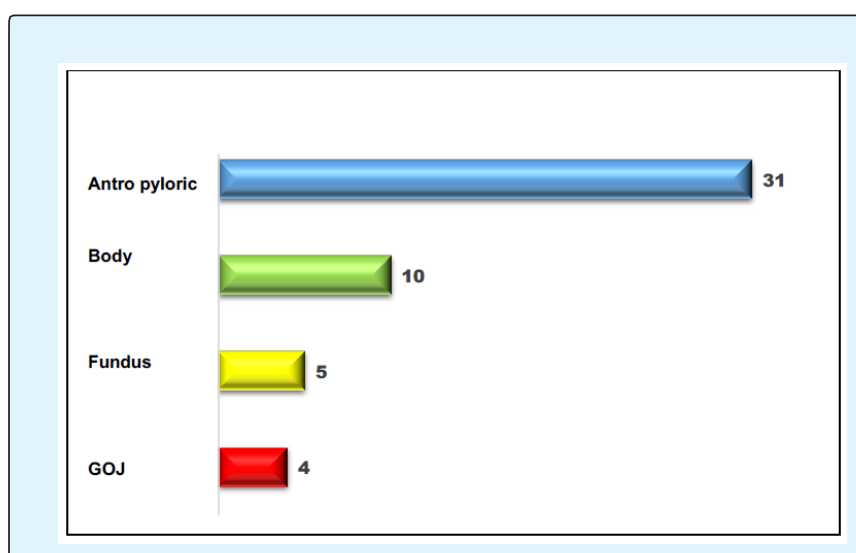

Figure 2: Distribution of lesions according to location.

At histology, 76\% of adenocarcinomas (ADKs) were of tubulous type, $16 \%$ were of tubulo papillary type, and $8 \%$ were independent-cell adenocarcinomas in the shape of "kitten-rings" with variable differentiation levels (Figure 3).

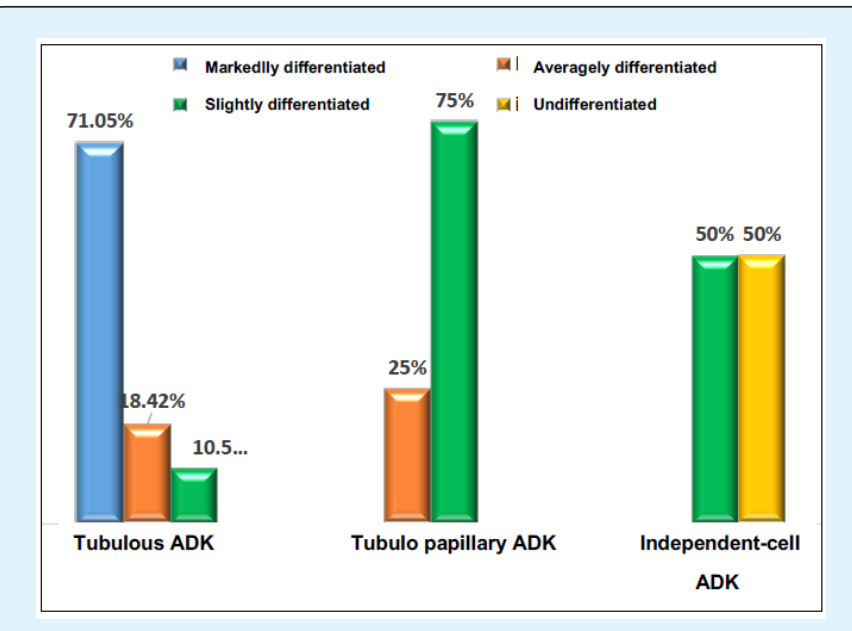

Figure 3: Differentiation level for each type of adenocarcinoma.

Immunohistochemistry performed on the 50 tumor samples was positive $(3+$ score $)$ in $8 \%$ (4) cases, ambiguous or equivocal (2+ score) in $4 \%$ (2) of cases, and negative ( 0 and $1+$ score) in $88 \%$ (44) of cases. For both ambiguous cases, hybridization technique was used. The study of the correlation between HER2 
overexpression and age showed that overexpression of the HER2 receptor was more common amongst patients below 50 years of age (Table 2 ).

\begin{tabular}{|c|c|c|c|}
\hline Age range & 0 and 1+ score & 2+ score & 3+ score \\
\hline Under 50 & $9(20.45 \%)$ & 0 & $3(75 \%)$ \\
\hline 50 and over & $35(79.55 \%)$ & $2(100 \%)$ & $1(25 \%)$ \\
\hline Total & $44(100 \%)$ & $2(100 \%)$ & $4(100 \%)$ \\
\hline
\end{tabular}

Table 2: Distribution of HER2 receptor coloring intensity scores by age groups.

A male predominance, with 3 patients $(75 \%)$, was found. The correlation between gender and HER2 overexpression was not significant $(\mathrm{p}=0.193)$. The HER2 receptor was only overexpressed in gastric ADKs. GOJ ADKs did not overexpress the HER2 receptor. However, no correlation was noted between location and HER2 receptor overexpression ( $p=0.47$ ). Only ulcero-budding tumors overexpressed the HER2 receptor. The correlation between the endoscopic appearance of the tumors and overexpression of the HER2 receptor was not significant ( $p=0.9508)$. Three-quarters $(75 \%)$ of adenocarcinomas that overexpressed the HER2 receptor were of a markedly differentiated tubulous type, and $1 / 4$ (25\%) were undifferentiated independent- cell ADKs. However, no significant link was found between the histological type and HER2 receptor overexpression $(p=0.116)$.

\section{Discussion}

On a world scale, gastric cancer constitutes a major public health problem [4] the prognosis of which varies greatly depending on its parietal and metastatic extension [6]. The most represented age group in our sampling $(56 \%)$ was people aged between 50 and 70 years. Gastric adenocarcinoma occurring at a late stage in an individual's life would be, according to Corréa's schema [7], the consequence of Helicobacter pylori infection theevolution of which is aggravated by the reaction of the host cell or of intercurrent environmental factors $[8,9]$. On the other hand, the incidence of gastroesophageal junction adenocarcinoma the main risk factor of which is gastroesophageal reflux, is increasing [9]. A male predominance was observed as well in our sampling as in those of authors, with ratios fluctuating between 1.3 and $2.5[8,10]$. The origin of this male predominance, although inexplicable, suggests a protective role of female hormones [8]. The macroscopic appearance corresponded to the different endoscopic aspects. Three modes of development - ulcero budding, budding and ulcerated were found in our sampling, with a predominance of the ulcero budding type, as in the sampling of Bassène, et al. [11]. Smooth lesions, vegetating polypoid tumors, diffuse infiltrating cancers (plastic linitis) and ulcerous cancers also known as 'malignant ulcers' are hardly found in the literature [6]. In most cases, the three aspects - ulcerated, vegetative and infiltrating- caused, together, an 'earlobule' cancer which is a large ulceration with a budding base dug into an infiltrating mass, and surrounded by an irregular roll of fat [6]. Overexpression of HER 2 has been detected in several cancers, and it especially involves the breast. Today, it is present in 10 to $30 \%$ of gastric adenocarcinomas and would be considered as a factor of poor prognosis [12]. Research on HER2 overexpression has become essential to the selection of patients for treatment by Herceptin ${ }^{\circledR}$ (trastuzumab). We found a relatively lower HER2 positivity rate in our study, compared to other samplings [12-14]. Although this rate is low in our study, it remains within the recommended limit in the literature which is between 7 and $34 \%[2,12]$. This overexpression rate difference could be explained by unequal sample size, but also by the choice of inclusion criteria. Indeed, we conducted a study that focused solely on biopsy specimens without considering the TNM stage, contrary to other authors who were interested in all locally-advanced gastric adenocarcinomas or metastatic GOJs [12-14]. Several studies focused on HER2 receptor expression and its correlation with clinico-histological parameters. In our study, univariate analysis did not show a correlation between gender, age, location, macroscopic appearance, histological type of the tumor, and HER2 receptor expression pattern. This is probably related to the small size of our sampling.

Other studies, notably those by Gravalos, et al. [15] and Tanner, et al. [13], had observed a more enhanced HER2 overexpression rate in patients younger than 65 years of age. However, the correlation between age and HER2 overexpression was not significant in any of those samplings; which corroborates the results of our study. Similarly, male predominance was observed in most samplings, particularly in the ToGA study [12], and in the samplings of Tanner, et al. [13]. But no correlation was found between gender and HER2 overexpression. Only gastric adenocarcinomas overexpressed the HER2 receptor; and no significant correlation between the tumor localization and HER2 overexpression was observed ( $p=0.47)$. On the other hand, for many other authors, HER2 overexpression was more frequent in GOJ adenocarcinomas than in gastric adenocarcinomas $[12,13,15]$. There was observed a link between tumor location and HER2 overexpression $(p=0.001)$ in the ToGA study [12]. 


\section{Open Access Journal of Microbiology \& Biotechnology}

In most studies, compared with our sampling, HER2 overexpression was less frequent in independent-cell ADKs, contrary to tubulous intestinal and tubule papillary types [5,12,15]. In the ToGA study [12] significant correlation was observed with $p=0.001$. This difference has also been described by other authors: Gravalos, et al. [15] who had observed a 7\% HER2 overexpression in independent-cell ADKs, and a 16\% overexpression in intestinal types with $p=0.276$.

Lordick, et al. [5], in their works that were presented at the European Cancer Organization Conference in 2007, concluded that there was a significantly different HER2 positivity between independent-cell ADKs (6\%) and intestinal type ADKs (34\%). However in the samplings of Zhang, et al. [16] published in 2009, HER2 overexpression was more frequent in independent-cell ADKs, with $26.7 \%$ against $7.1 \%$ for intestinal types (with $p=0.05$ ).

\section{Conclusion}

This work presents the results of a preliminary study the aim of which is to estimate the prevalence of HER2 overexpression in gastric cancers in Dakar. The data from our study tend to suggest the systematic demand for HER2 test in any patient with a gastric or gastroesophageal junction adenocarcinoma condition. For this, a multidisciplinary approach involving gastroenterologists, oncologists, surgeons, and pathologists would be necessary for optimal care to be given to patients.

\section{Conflicts of Interest}

The authors do not declare any conflicts of interest.

\section{Contribution of the Authors}

All of the authors contributed substantially to the design of the study, data acquisition, data analysis and interpretation, to editing the article, and unanimously approved the submission of the final version of this paper.

\section{References}

1. Wagner AD, Grothe W, Haerting J, Kleber G, Grothey A, et al. (2006) Chemotherapy in advanced gastric cancer: a systematic reviewand meta-analysis based on aggregate data. J Clin Oncol 24(18): 2903-2909.
2. Monges G (2011) HER2 diagnostic dans les cancers gastriques et de la jonction oeso- gastrique. Hepatogastro et Oncologie digestive 18(4): 407- 409.

3. Penault-Llorca F, Monges G (2012) Score HER2 pour les carcinomes gastriques. Principales différences avec le score HER2 des carcinomes mammaires Réalisation en pratique. Correspondances en OncoThéranostic 1(2): 1-4.

4. Thésaurus national de cancérologie digestive (2018) Disponible en ligne sur.

5. Lordick F, Bang YJ, Kang YK (2017) Test HER2 dans le cancer gastrique: résultats d'une réunion d'experts allemands. Journal de recherche sur le cancer et d'oncologie 143(5): 835-841.

6. Adem C, Petit T (2014) memento de Pathologie.4ème edition. Editions Vernazobres- Grego, Paris.

7. Correa P, Piazuelo B (2012) The gastric precancerous cascade. J Dig Dis 13(1): 2-9.

8. Lamarque D (2008) Épidémiologie de l'adénocarcinome de l'estomac. Mini-revue HépatoGastroentérologie 15(2): 101-108.

9. Lambert R (2006) Épidémiologie du cancer gastrique dans le monde. Cancérologie digestive 2(1): 31-37.

10. Neugut AI, Hayek M, Howe G (2006) Epidemiology of gastric cancer. Semin Oncol 15: 50-62.

11. Bassene ML, Sy D, Dia D, Diallo S, Gueye MN, et al. (2014) Le cancer gastrique : étude descriptive de 101 cas dans le centre d'endoscopie digestive du CHU Aristide Le Dantec. Médecine et Santé Tropicales 25: 377-380.

12. Bang YJ, Van Cutsem E, Feyereislova A, Chung HC, Shen L, et al. (2010) Trastuzumab in combination with chemotherapy versus chemotherapy alone for treatment of HER2-positive advanced gastric or gastro-oesophageal junction cancer (ToGA): a phase 3 , open label randomised controlled trial. Lancet 376(9742): 687-697.

13. Tanner M, Hollmén M, Junttila TT, Kapanen AI, Tommola S, et al. (2005) Amplification of HER-2 in gastric carcinoma: association with Topoisomerase Ilalpha gene amplification, intestinal type, poor prognosis and sensitivity to Trastuzumab. Ann Oncol 16(2): 273-278. 
14. Park DI, Yun JW, Park JH, Oh SJ, Kim HJ, et al. (2006) Her2/neu amplification is an independent prognostic factor in gastric cancer. Dig Dis Sci 51: 1371-1379.

15. Gravalos C, Jimeno A (2008) HER2 in gastric cancer: a new prognostic factor and a novel therapeutic target. Annals of Oncology 19(9): 1523-1529.
16. Zhang XL, Yang YS, Xu DP, Qu JH, Guo MZ, et al. (2009) Comparative study on overexpression of HER2/neu and HER3 in gastric cancer. World J Surg 33(10): 2112-2118. 